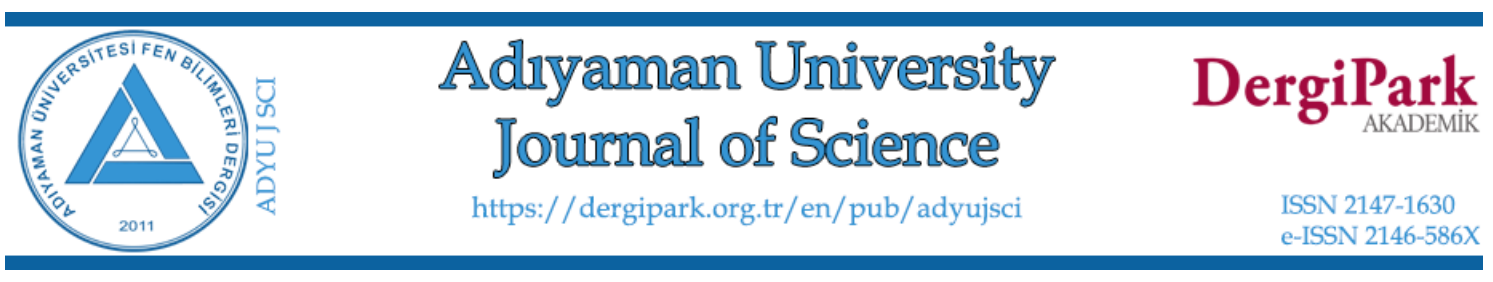

\title{
G-banded Karyotypes of Some Species in Gliridae (Mammalia: Rodentia) from Turkey
}

Teoman KANKILIÇ ${ }^{1, *}$, Perinçek Seçkinozan ŞEKER ${ }^{2}$, Engin SELVİ ${ }^{3}$, Beytullah ÖZKAN ${ }^{4}$, Nuri YİĞİT ${ }^{3}$, Ercüment ÇOLAK ${ }^{3}$

\author{
${ }^{I}$ Niğde Ömer Halisdemir University, Faculty of Arts and Science, Department of Biotechnology, Niğde \\ Turkey \\ tkankilic@ohu.edu.tr,ORCID: 0000-0002-9576-5887 \\ ${ }^{2}$ Artvin Çoruh University, Artvin Vocational School, Hunting and Wildlife Program, Artvin, Turkey \\ seckinperincek@artvin.edu.tr,ORCID:0000-0002-6103-4840 \\ ${ }^{3}$ Ankara University, Faculty of Science, Department of Biology, Ankara, Turkey \\ eselvi@ankara.edu.tr,ORCID:0000-0001-5370-3023 \\ colak@science.ankara.edu.tr,ORCID:0000-0001-5826-1615 \\ nyigit@science.ankara.edu.tr,ORCID:0000-0001-8426-2144 \\ ${ }^{4}$ Trakya University, Faculty of science, Department of Biology, Edirne, Turkey \\ beytullahozkan@trakya.edu.tr,ORCID:0000-0003-0050-7031
}

\begin{abstract}
The results of a cytogenetic study on some representatives of Gliridae from Turkey were introduced. The G-, C-, and AgNOR banded karyotypes of Muscardinus avellanarius abanticus from Abant (Bolu), and the G-banded karyotype of Myomimus roachi from Thrace were presented for the first time. Additionally, the G-banded karyotypes of Dryomys nitedula, and Myoxus glis were analysed. Because of not including a secondary constriction and the smallest chromosome being metacentric instead of acrocentric in the autosomal set, the karyotype of $M$. a. abanticus was different from that of M. a. trapezius. With the comparison of obtained G-banded patterns belonging to the other Glirid species, it was detected that obtained karyotypes displayed consistency at a great extent with the previously determined karyotypes.
\end{abstract}


Keywords: Gliridae; G-banding; Karyotype; Turkey.

Türkiye'de Yayılış Gösteren Gliridae (Mammalia: Rodentia) Familyasındaki Bazı Türlerin G-bantlı Karyotipleri

Öz

Bu çalışmada Türkiye'de yayılış gösteren bazı Gliridae temsilcileri üzerinde yapılan bir sitogenetik çalışmanın sonuçları sunuldu. Abant'tan (Bolu) Muscardinus avellanarius abanticus'un G-, C- ve AgNOR bantlı karyotipleri ile Trakya'dan Myomimus roachi'nin G-bantlı karyotipi ilk kez sunuldu. Ek olarak, Dryomys nitedula ve Myoxus glis'in G-bantl1 karyotipleri analiz edildi. Otozomal sette ikincil bir daralma olmaması ve en küçük kromozomun akrosantrik yerine metasentrik olması nedeniyle, M. a. abanticus'un karyotipinin $M$. a. trapezius'un karyotipinden farklı olduğu tespit edildi. Farklı lokalitelerde yaşayan Glirid türlerinin elde edilen G-bantlı karyotiplerinin daha önceki çalışmalarda belirlenen karyotiplerle büyük ölçüde tutarlılık gösterdiği tespit edildi.

Anahtar Kelimeler: Gliridae; G-bantlama; Karyotip; Türkiye.

\section{Introduction}

Gliridae Thomas, 1897 is one of the oldest extant families of order Rodentia. Members of this family are known for their long-term (5-6 months) hibernation. They can occupy many different habitats; such as woods, thickets, orchards, rocky areas in the forest, steppes, and deserts. Species within this family are mostly found in Europe and Asia Minor, although some of them live in Africa, Russia, India, China, and Japan [1,2]. The family consists of 9 genera including 28 living species [2]. There are 11 species in the family whose distribution range is limited to the western Palearctic; seven of them (Myoxus glis, Dryomys nitedula, Dryomys laniger, Eliomys melanurus, Myomimus roachi, Muscardinus avellanarius, and Myomimus setzeri) lived in Turkey [3]. Among all, the most common dormouse species in Turkey are M. glis, D. nitedula, and M. avellanarius. The remaining species have a more limited geographical distribution range. $M$. roachi, also known as Roach's mouse-tailed dormouse, is present only in a limited area in the western part of Thrace and Turkey. Another Myomimus species, M. setzeri, also known as Setzer's mouse-tailed dormouse, has been recorded from eastern Anatolia adjacent to Iran. Despite $E$. melanurus is found in Egypt, Iraq, Israel, Jordan, Lebanon, Libya, Saudi Arabia, Syria and Turkey (Şanlıurfa), D. laniger that is an endemic hibernator species has a limited distribution in the Taurus Mountains [3]. 
Until this time, there have been numerous studies that examine the characteristics of karyological of Glirid taxa in Europe and Turkey. [4, 5]. Beyond that the conventional karyotypes of most species in Gliridae from Turkey have been determined by previously performed studies $[6,7]$. Notwithstanding, there is still lack of information about the banded and even conventional karyotypes of many taxa in this family. Heretofore, two subspecies of M. avellanarius, also called the hazel dormouse, in Turkey have been identified based on the morphological differences between geographically very distant populations of this species [8, 9]. The first one, $M$. $a$. trapezius, has been described from Coşandere (Trabzon), while, the second one, M. a. abanticus, has been identified from Abant (Bolu). Various karyotype studies including conventional, C- and G- banding techniques have often been focused on the European populations of M. avellanarius [10-16], and little has been known about the karyology of the Turkish populations [17, 18]. The C- and G-banded karyotypes in the populations of M. a. trapezius from Trabzon and Ordu have been previously reported $[17,18]$. On the other hand, even conventional karyotype of the M. $a$. abanticus is still unknown. The conventional and AgNOR- banded karyotype of M. roachi has been studied by Civitelli et al. [19]. However, the C- and G-banded karyotypes of M. roachi from Turkey have not been reported up to the present. The conventional stained and banded karyotype of $D$. nitedula has been detected from various parts of its geographic distribution range in Turkey $[6,7,19,20]$. In contrast to this, the C- and G- and AgNOR-banded karyotype of this species has been studied on the limited number of specimens from the restricted number of areas in Turkey $[7,19,20]$. The conventional karyotype of fat dormouse, M. glis, has been investigated in specimens from both Anatolia and Thrace [21, 19]. The C- and G- banded karyotype of this species have been studied from different parts of Black Sea regions [20, 22].

On the members of the Gliridae family from Turkey, the conventional karyotype studies have been performed more often, however, karyotype banding studies have been limited. The increase in the number of banding studies conducted on the members of this family, which has a wide range in our country, will make it easier to determine possible intraspecific variations within the species of this rodent family; and thus, this will enable us to directly contribute to the understanding of our country's biodiversity and hence global biodiversity. Based on this thought, the current study primarily presented the banded karyotypes of the representatives of Gliridae from Turkey (M. a. abanticus, M. a. trapezius, M. roachi, D. nitedula, and Myoxus glis) to fill the gaps in our knowledge about chromosome banding patterns of dormouse species. In addition, the G-, C-, and AgNOR-banded karyotypes of M. a. abanticus were introduced for the first time.

\section{Materials and Methods}


Karyotype analyses were carried out on 51 specimens belonging to $M$. a. abanticus, $M$. roachi, D. nitedula, and $M$. glis in the Gliridae family. The number of specimens, sample designations, and collecting sites for each species was identified in Table 1 and Fig. 1. Animal samples were captured by the fieldwork performed in accordance with the legal permission (no: 72784983-488.04-150036) given by the Republic of Turkey Ministry of Agriculture and Forestry, General Directorate of Nature Conservation and National Parks. Experimental processes were conducted according to the animal experiments local ethics committee decision provided by the Animal Experiments Local Ethics Committee of Ankara University (no. 2015-6-105).

Karyotype preparations were obtained from the fresh bone marrow of colchicine treated animals following the method of Ford and Hamerton [23]. To define autosomal and sexual chromosomes pairs, the C-, G- and AgNOR staining techniques were employed. The G-banding processes of the chromosomes were carried out in accordance with the process introduced by Seabright [24]. Constitutive heterochromatin and nucleolus organizer regions (NORs) were detected by following the staining techniques of Sumner [25] and Howell and Black [26], respectively. A total of 10 slides were made from each sample and nearly 20 well-spread metaphase plates were examined. The slides were photographed with the Nikon DS-Ri2 stereo binocular microscope. Chromosome numbers were determined by attentively counting of wellspreading metaphase plates. The most frequently observed chromosome counts were regarded as valid karyotypes. The diploid number of chromosomes (2n), the total numbers of chromosomal arms (NF), and the numbers of autosomal arms (NFa), as well as the $\mathrm{X}$ and the $\mathrm{Y}$ chromosomes, were classified. All chromosomes were arranged from bigger to smaller and noted to be the metacentric, submetacentric and acrocentric according to their centromere positions, consistent with the Levan et al. [27]. The skins, skulls, and karyotype preparations of all examined specimens were deposited at the Niğde Ömer Halisdemir University, Niğde, Turkey.

\section{Results}

The G-, C-, and AgNOR-banded karyotype of M. a. abanticus were studied for the first time. The karyotype of three populations from Abant (Bolu) - type locality of M. a. abanticus-, Uludağ (Bursa) and Yı̆̆ılca (Düzce) in Turkey had $2 n=46, N F=92$ and NFA $=88$ values. All the autosomal chromosomes were bi-armed (meta- and submetacentric or subtelocentric pairs) in gradually decreasing size. The $\mathrm{X}$ chromosome was a medium-sized metacentric, while the $\mathrm{Y}$ chromosome was a small-sized acrocentric. AgNOR staining revealed that the nucleolar organizer regions positioning in the secondary constrictions were localized in the $20^{\text {th }}$ and $22^{\text {nd }}$ autosomal pairs. All detected NORs were heteromorphic and observed only in one of the homologs. Most of the autosomal chromosomes enjoyed apparent $\mathrm{C}$-positive bands in pericentromeric regions, while, 
C-bands in some chromosomes were nebulous. The sexual chromosomes also had dark C-bands. (Fig. 2).

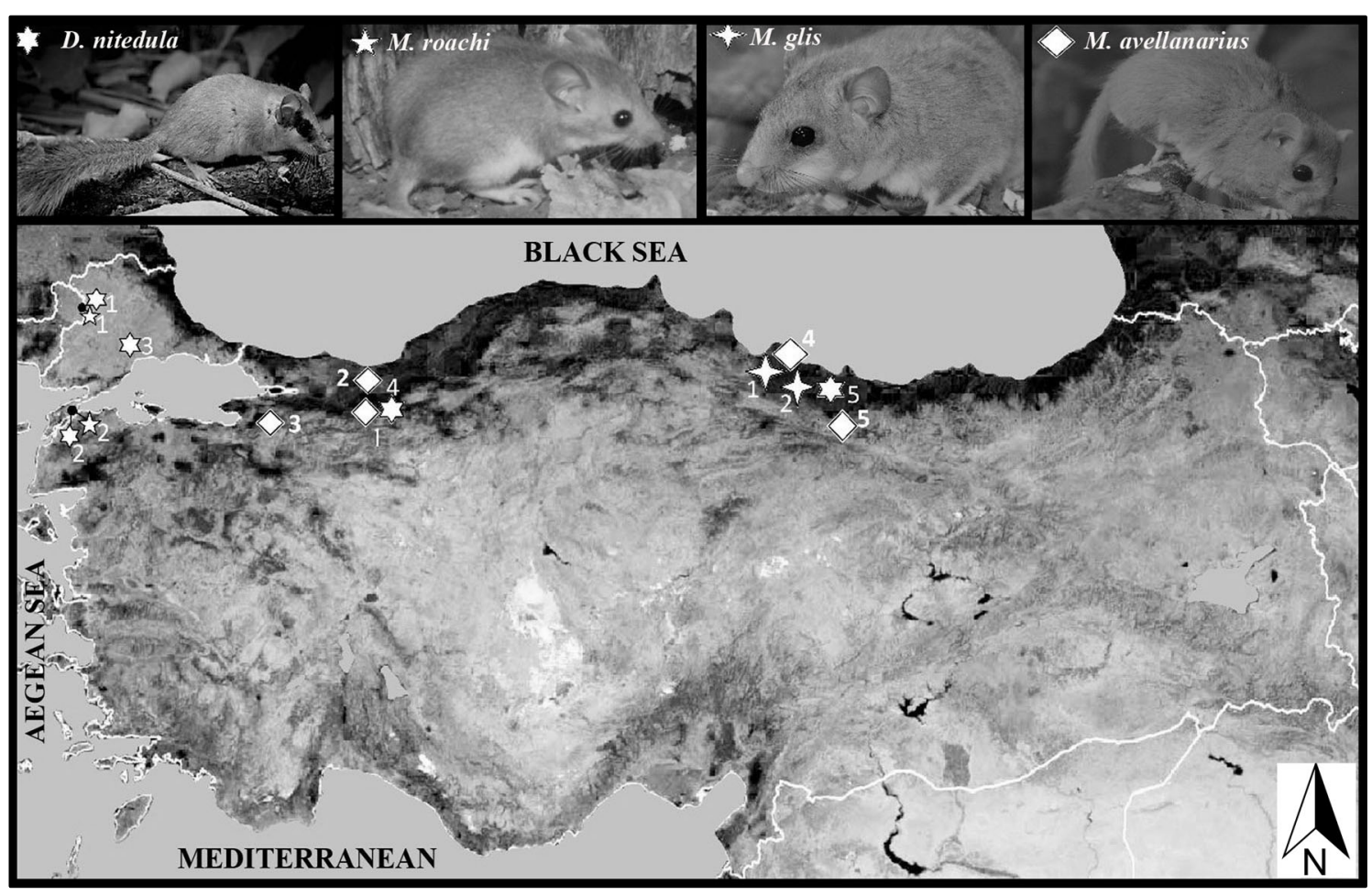

Figure 1: The map showing collecting sites of the samples, the numbers and symbols in the map correspond to the localities and species given in Table 1

Additionally, the G- banded karyotypes of M. a. trapezius from Ordu-Ulubey and GiresunBulancak were presented. The detected karyotype consisted of $2 \mathrm{n}=46, \mathrm{NF}=90$, and $\mathrm{NFa}=86$ values. The $\mathrm{X}$ chromosome was larger metacentric and $\mathrm{Y}$ chromosome was acrocentric. This karyotype was different from the karyotype of M. a. abanticus, because of including a secondary constriction in the $20^{\text {th }}$ chromosome pair and the smallest chromosome being acrocentric instead of metacentric in the autosomal set (Fig. 3).

The G- banded karyotype of $M$. roachi was detected for the first time. The karyotype of three specimens from Edirne and Çanakkale from Thrace in the European part of Turkey had the karyotype including $2 \mathrm{n}=44, \mathrm{NFa}=84$ and $\mathrm{NF}=88$ values. All the autosomal chromosomes were bi-armed (meta- or submetacentric pairs) of decreasing size. In the karyotypes, the $\mathrm{X}$ chromosome was a medium-sized submetacentric, while the $\mathrm{Y}$ chromosome was a medium-sized metacentric (Fig. 4A). 
Table 1: The number of specimens, sample designations, collecting sites and karyological characteristics for each species. (NFa: autosomal fundamental number NF: chromosome arm numbers)

\begin{tabular}{|c|c|c|c|c|c|c|c|c|}
\hline Species & $\begin{array}{c}\text { Map } \\
\text { Number }\end{array}$ & $\begin{array}{c}\text { Localities } \\
\text { (Latitude/Longitude) }\end{array}$ & Total & $\hat{0}$ & q & $2 n$ & $\mathrm{NFa}$ & $\mathrm{NF}$ \\
\hline \multirow[t]{3}{*}{ Myoxus glis ( } & 1 & Giresun-Bulancak & 1 & 1 & - & 62 & 120 & 124 \\
\hline & & $\left(40^{0} 56^{\prime} 08^{\prime \prime} \mathrm{N} / 38^{0} 13^{\prime} 51^{\prime \prime} \mathrm{E}\right)$ & & & & & & \\
\hline & 2 & $\begin{array}{l}\text { Ordu-Ulubey-Yukarıkızılen } \\
\left(40^{\circ} 46^{\prime} 38^{\prime \prime} \mathrm{N} / 37^{0} 42^{\prime} 39^{\prime \prime} \mathrm{E}\right)\end{array}$ & 2 & 1 & 1 & 62 & 120 & 124 \\
\hline \multirow[t]{10}{*}{ Dryomys nitedula ( } & 1 & Edirne-Orhaniye-Bağlık & 1 & - & 1 & 48 & 92 & 96 \\
\hline & & $\left(41^{0} 31^{\prime} 07^{\prime \prime} \mathrm{N} / 26^{0} 39^{\prime} 09^{\prime \prime} \mathrm{E}\right)$ & & & & & & \\
\hline & 2 & Çanakkale-Gelibolu-Sütlüce & 1 & - & 1 & 48 & 92 & 96 \\
\hline & & $\left(40^{0} 20^{\prime} 35^{\prime \prime} \mathrm{N} / 26^{0} 36^{\prime} 03^{\prime \prime} \mathrm{E}\right)$ & & & & & & \\
\hline & 3 & Tekirdağ-Kumbağı-Naip & 1 & - & 1 & 48 & 92 & 96 \\
\hline & & $\left(40^{0} 52^{\prime} 25^{\prime \prime} \mathrm{N} / 27^{0} 25^{\prime} 31^{\prime \prime} \mathrm{E}\right)$ & & & & & & \\
\hline & 4 & Bolu-Abant & 1 & - & 1 & 48 & 92 & 96 \\
\hline & & $\left(40^{0} 35^{\prime} 41^{\prime \prime} \mathrm{N} / 31^{0} 16^{\prime} 57^{\prime \prime} \mathrm{E}\right)$ & & & & & & \\
\hline & 5 & Giresun-Bulancak & 1 & 1 & - & 48 & 92 & 96 \\
\hline & & $\left(40^{0} 55^{\prime} 12^{\prime \prime} \mathrm{N} / 38^{0} 12^{\prime} 56^{\prime \prime} \mathrm{E}\right)$ & & & & & & \\
\hline \multirow[t]{6}{*}{ Myomimus roachi $(\star)$} & 1 & Edirne-Orhaniye-Bağlık & 1 & - & 1 & 44 & 84 & 88 \\
\hline & & $\left(41^{0} 29^{\prime} 50^{\prime \prime} \mathrm{N} / 26^{0} 38^{\prime} 49^{\prime \prime} \mathrm{E}\right)$ & & & & & & \\
\hline & 1 & Edirne-Azatlı & 1 & - & 1 & 44 & 84 & 88 \\
\hline & & $\left(41^{0} 29^{\prime} 38^{\prime \prime} \mathrm{N} / 26^{0} 42^{\prime} 03^{\prime \prime} \mathrm{E}\right)$ & & & & & & \\
\hline & 2 & Çanakkale-Gelibolu-Sütlüce & 1 & 1 & - & 44 & 84 & 88 \\
\hline & & $\left(40^{0} 20^{\prime} 54^{\prime \prime} \mathrm{N} / 26^{0} 36^{\prime} 47^{\prime \prime} \mathrm{E}\right)$ & & & & & & \\
\hline \multirow[t]{10}{*}{ Muscardinus avellanarius $(\diamond)$} & 1 & Bolu-Abant-Soğuksu & 7 & 4 & 3 & 46 & 88 & 92 \\
\hline & & $\left(40^{0} 36^{\prime} 49^{\prime \prime} \mathrm{N} / 31^{0} 17^{\prime} 56^{\prime \prime} \mathrm{E}\right)$ & & & & & & \\
\hline & 2 & Düzce-Yığılca & 4 & 3 & 1 & 46 & 88 & 92 \\
\hline & & $\left(40^{0} 57^{\prime} 31^{\prime \prime} \mathrm{N} / 31^{0} 27^{\prime} 04^{\prime \prime} \mathrm{E}\right)$ & & & & & & \\
\hline & 3 & Bursa-Uludağ & 2 & 1 & 1 & 46 & 88 & 92 \\
\hline & & $\left(40^{0} 07^{\prime} 06^{\prime \prime} \mathrm{N} / 29^{0} 07^{\prime} 11^{\prime \prime} \mathrm{E}\right)$ & & & & & & \\
\hline & 4 & Ordu-Ulubey & 6 & 3 & 3 & 46 & 86 & 90 \\
\hline & & $\left(40^{0} 52^{\prime} 36^{\prime \prime} \mathrm{N} / 37^{0} 45^{\prime} 32^{\prime \prime} \mathrm{E}\right)$ & & & & & & \\
\hline & 5 & Giresun-Bulancak & 4 & 2 & 2 & 46 & 86 & 90 \\
\hline & & $\left(40^{0} 55^{\prime} 57^{\prime \prime} \mathrm{N} / 38^{0} 14^{\prime} 52^{\prime \prime} \mathrm{E}\right)$ & & & & & & \\
\hline
\end{tabular}




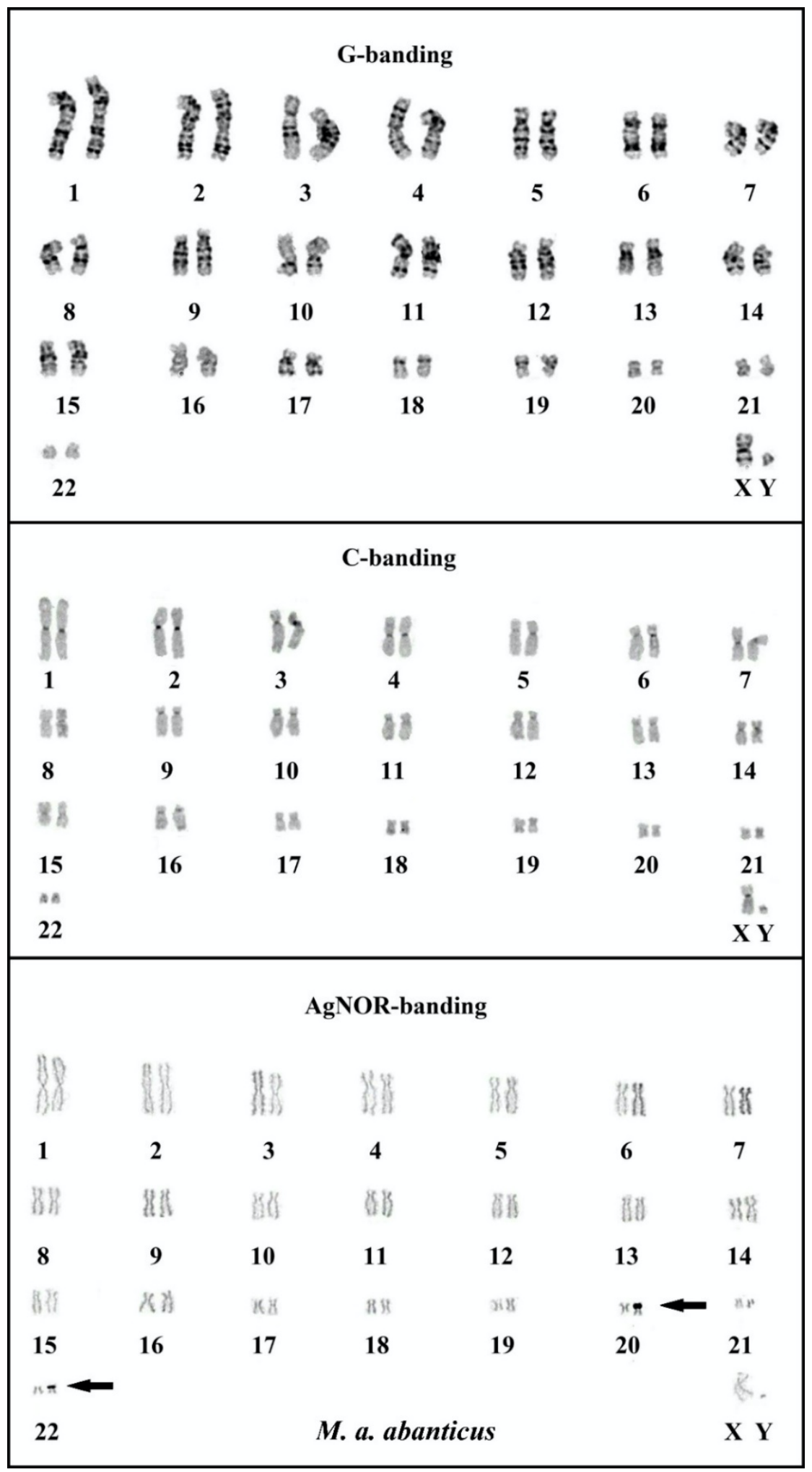

Figure 2: The G-, C- and AgNOR- banded karyotype of M. a. abanticus from Abant-Bolu. The arrows indicate the position of the heteromorphic active AgNOR regions 


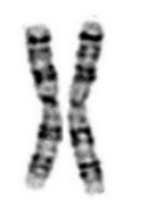

1

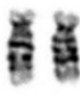

8

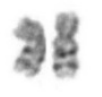

15

22

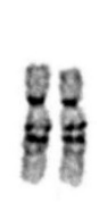

2

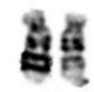

9

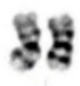

16

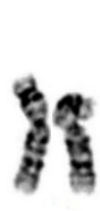

3

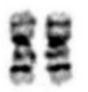

10

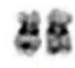

17

\section{G- banding}

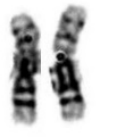

4
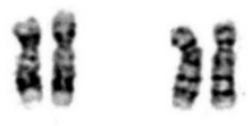

6

7

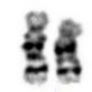

11
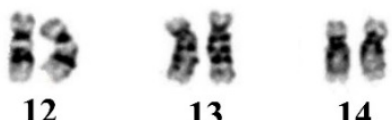

13

14
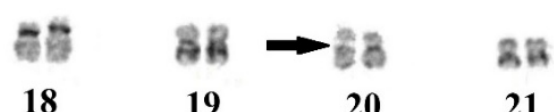

21

20

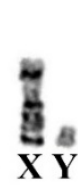

Figure 3: The G- banded karyotype of $M$. a. trapezius from Ulubey-Ordu. The arrow indicates the secondary construction

The karyotype of D. nitedula from Thrace located in the European Turkey and Anatolia was studied using the G-banding technique. The karyotypes of five specimens collected from five localities had the values of $2 \mathrm{n}=48, \mathrm{NF}=96$ and $\mathrm{NFa}=92$. It was determined that the karyotypes of all specimens consisted of 23 pairs of large and small meta-, submeta- and subtelocentric autosomal chromosomes. The first autosomal pair was frankly bigger than the other autosomal pairs in the complement. In conformity with the findings of previous studies, it was detected that $21^{\text {st }}$ autosomal chromosomes were in a heterozygous secondary constriction condition in this karyotype. The X chromosomes were identified to be in the large and submetacentric shape (Fig. 4B).

The G-banded karyotype of M. glis from Turkey was investigated. The karyotype having the values of $2 \mathrm{n}=62, \mathrm{FN}=124, \mathrm{NFa}=120$ was found in two $M$. glis specimens from two different localities of Anatolia. Except for the Y- chromosome, all chromosomes, including X-as well, in the karyotype were noted to be bi-armed, meta- and submetacentric chromosomes. The $17^{\text {th }}$ autosomal pair appeared to carry a secondary constriction in the karyotype. The X-chromosome was determined to be a large-sized and metacentric element, while the Y-chromosome was detected to be dot-like and most likely acrocentric element (Fig. 4C). 


\begin{tabular}{|c|c|c|c|c|c|c|}
\hline 1 & $\begin{array}{c}3 \\
2\end{array}$ & 3 & $\begin{array}{c}\text { th } \\
4\end{array}$ & 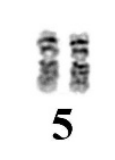 & 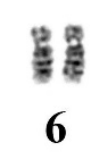 & $\begin{array}{c}g \\
7\end{array}$ \\
\hline 侽黑 & 5 & 籍 & 를 & 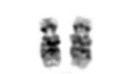 & $\pm E$ & 28 \\
\hline 8 & 9 & 10 & 11 & 12 & 13 & 14 \\
\hline S & g్ & 88 & 58 & 80 & $8 s$ & $B$ \\
\hline 15 & 16 & 17 & 18 & 19 & 20 & 21 \\
\hline $\mathbf{A}$ & \multicolumn{5}{|c|}{ M. roachi } & $\mathbf{X}^{*} \mathbf{Y}$ \\
\hline 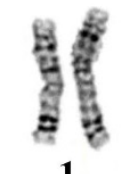 & 8 & B & है है & $\frac{6}{6}$ & 83 & 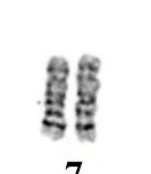 \\
\hline 1 & 2 & $\begin{array}{c}3 \\
8\end{array}$ & $\begin{array}{l}4 \\
42\end{array}$ & $\stackrel{5}{3}$ & 6 & 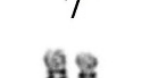 \\
\hline 8 & 9 & $\begin{array}{l}10.5 \\
10\end{array}$ & 영려 & $\begin{array}{l}\text { 9.9. } \\
12\end{array}$ & 13 & 8 \\
\hline है영 & 유 해 & 염둄 & F & 66 & $a$ & $\overrightarrow{B S}_{\mathrm{Ba}}$ \\
\hline 15 & 16 & 17 & 18 & 19 & 20 & 21 \\
\hline ล & $B=$ & \multirow{2}{*}{\multicolumn{4}{|c|}{ D. nitedula }} & 重 \\
\hline $\mathbf{n}^{23}$ & 24 & & & & & $\mathbf{X Y}$ \\
\hline 蛋雪 & 88 & 28 & รี है & คิ & ํำ है & 8 \\
\hline 1 & 2 & 3 & 4 & 5 & 6 & 7 \\
\hline ్ㅜำ & $8 \%$ & 88 & ซื ถุ & ถิำ & 88 & 욥몀 \\
\hline 8 & 9 & 10 & 11 & 12 & 13 & 14 \\
\hline 88 & 88 & $\rightarrow 88$ & my & $8 \mathrm{~B}$ & $8 \%$ & $\mathbb{m}$ \\
\hline 15 & 16 & 17 & 18 & 19 & 20 & 21 \\
\hline 32 & 28 & 85 & 202 & 28 & 83 & 88 \\
\hline 22 & 23 & 24 & 25 & 26 & 27 & 28 \\
\hline a & 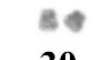 & \multirow{3}{*}{\multicolumn{3}{|c|}{ M. glis }} & & 50 \\
\hline 29 & 30 & & & & & $\mathbf{X Y}$ \\
\hline C & & & & & & \\
\hline
\end{tabular}

Figure 4: G- banded karyotypes of $M$. roachi from Edirne (A), D. nitedula from Tekirdağ (B), and M. glis from $\operatorname{Ordu}(\mathrm{C})$. The arrows indicate the secondary construction in the karyotypes 


\section{Discussion}

Identifying intra-specific variations is the most fundamental step in documenting biodiversity in a particular region. In this sense, the variations hidden in the genome of both plant and animal species in our country are tried to be revealed by using a wide variety of markers, including karyotype analysis [7, 17, 19, 28, 29]. Karyotype variations are an easy-to-apply method used to determine genetic variation. In this study, carried out for this purpose, the G-, C-, and AgNOR-banded karyotypes of M. a. abanticus and the G-banded karyotypes of M. roachi from Turkey were presented for the first time. Additionally, the G-banded karyotypes of $M$. $a$. trapezius, D. nitedula, and M. glis were submitted as well.

The karyotype of M. avellanarius was investigated from only two localities in north-eastern Anatolia throughout Turkey until now. Those obtained karyotypes belonged to the M. a. trapezius, known subspecies of this species from the region. The smallest autosomal pair in investigated karyotypes was considered to be subtelocentric in the Trabzon population or acrocentric in the Ordu population. Accordingly, two karyotype forms with $\mathrm{NFa}=86$ or $\mathrm{NFa}=88$ values were determined for this subspecies based on the morphological difference of the smallest pair [17, 18]. The G- banded karyotype of M. a. trapezius presented by this study included the values of $2 \mathrm{n}=46, \mathrm{NF}=90$ and $\mathrm{NFa}=86$ to be compatible with the karyotype determined by Şekeroğlu et al. [17]. The karyotype we identified from Ulubey-Ordu included a secondary constriction in the $20^{\text {th }}$ chromosome pair, similar to the karyotype of M. a. trapezius revealed by Şekeroğlu et al. [17] and Doğramacı and Kefelioğlu [18]. Also, the autosomal and sex chromosome morphologies in the karyotype of M. a. trapezius determined by this study and also those of previously presented one by Şekeroğlu et al. [17] were nearly the same as those of European populations of $M$. avellanarius except for the karyotype introduced by Doğramacı and Kefelioğlu [18] [4, 5]. In this context, it is necessary to open a separate parenthesis to the study of Peshev and Delov [15]. The researchers stated in their study that $M$. a. avellanarius had a value of $\mathrm{NFa}=88$. However, it is clearly seen in the presented idiogram and the text of the study that the smallest autosomal chromosome pair is acrocentric. We think that this $(\mathrm{NFa}=88)$ may have arisen from a printing error. Therefore, this species should have an NFa of 86 instead of 88 . Considering that, the NFa $=88$ value is only seen in the populations of M. avellanarius from Turkey.

The karyotype of M. a. abanticus from Abant-Bolu was described for the first time by the current study and it was detected that the karyotype had $2 n=46, N F=92$ and NFA $=88$ values. Obtained karyotype was substantially compatible with the karyotype of Dogramacı and Kefelioğlu [18] except to not include a secondary constriction. This karyotype was different from the karyotype of M. a. trapezius in two ways. The first was that the detected karyotype of M. a. 
abanticus did not include a secondary constriction. The second was that the smallest chromosome in the autosomal set was metacentric instead of acrocentric. By using silver-nitrate staining, the nucleolar organizer region was localized in the secondary constrictions in autosomal pair no. 20 and 22. All observed NORs were heteromorphic and occurred in differ homologues (Fig. 2).

Although the conventional karyotype of M. roachi from Thrace was known, however, no information about the banded karyotype of this species has been imparted so far. This deficiency has been tried to be compensated to a certain extent by this study presenting the G-banded karyotype. The results related to autosomal chromosomal set complied with those of Civitelli et al. [19]. Unlike this study, Y chromosome in the sample from the same locality was identified as metacentric rather than acrocentric.

That the karyotype of $D$. nitedula from various parts of Turkey (both from Thrace and Anatolia) had a steady karyotype value of $2 \mathrm{n}=48 \mathrm{FN}=96$ and $\mathrm{NFa}=92$ consistent with the results of previous studies were determined. The autosomal complement was entirely composed of the variable numbers of large and small, bi-armed chromosomes in the form of meta-, submetaor partly subtelocentric. In the karyotypes obtained by many previous studies, variations that were thought by us as not obvious in the shape and size of the chromosomes were found. Since it was thought that revealed chromosomal morphologies may have changed according to the researchers' perspective, no grouping attempts with respect to chromosome morphology were made in this study. Our results were found to be consistent with those of Doğramacı and Kefelioğlu [6], Şekeroğlu and Şekeroğlu [20], and Arslan et al. [7] including samples from Anatolia, and Mitsainas et al. [30] including the populations of D. nitedula from Greece. The karyotype introduced by the current study also comprised the secondary construction in the $21^{\text {st }}$ chromosome pair, as it was detected by previous studies. Three Dryomys species, D. laniger, D. nitedula and D. pictus have been reported from Turkey until this time [2,3]. From these species, D. nitedula populations in Turkish Thrace were mostly assigned to D. $n$. wingei [2]. Another subspecies of this species, $D . n$. phrygius, thought to be an endemic to Turkey, were firstly reported from western Anatolia [31], but so far, their taxonomic status has not been clarified in detail. Our results based on the sampling from both Thrace and Anatolia showed that there was no karyological difference between G- banded karyotypes of two subspecies.

Obtained karyotype having $2 \mathrm{n}=62$ diploid chromosome number in the two populations of M. glis by the current study was also previously determined in European and Asian populations $[12-15,19,20,21,22,30]$. Some chromosomal differences in the karyotypes of this species have been found before, even if the karyotype structures were homogeneous on a large scale. For example, the presence of a pair of acrocentric chromosomes in the autosomal set has been reported 
in Bulgarian populations [15]. However, a similar situation was not observed in the karyotypes presented by the current study; all the autosomal chromosomes were bi-armed, mostly congruent with the results of the previous studies. In addition, the secondary constriction in a small-sized pair has been frequently described in most examined populations of this species from Europe and Turkey $[14,20,30]$. Similar to them, the $17^{\text {th }}$ autosomal pair appeared to carry a secondary constriction in the karyotype determined by the current study. Mitochondrial DNA sequence analyses revealed that there is an amazing genetic homogeneity within the distribution range of the populations of this species not only in Turkey, but also in the whole of Europe [32]. This may be considered to be an indicator that the İstanbul and Çanakkale straits, and the Marmara Sea, obstacles for the terrestrial connection between Europe and Asia continentals, are not an effective geographic barrier for the gene flow between the populations of the edible dormouse. However, it is clear that more evidence is required for the solution of such complex biogeographical events. The karyotype data reported here and supporting the aforesaid genetic homogeneity can be considered as evidence required for the explanation of the mentioned situation.

\section{Conclusions}

By the results of the current karyotype study on some representatives of Gliridae from Turkey, the G-, C-, and AgNOR banded karyotypes of M. a. abanticus from Abant (Bolu), and the G-banded karyotype of $M$. roachi from Thrace were presented for the first time. With the examination and comparison of the determined findings, it was demonstrated that the intraspecific variations can be easily revealed by the karyotype. Available karyological variations in the determined karyotypes should be considered to be the noteworthy steps for the populations' differentiation. Of course, a strong genetic difference at the subspecies level between M. $a$. abanticus and M. a. trapezius may not be mentioned at this stage. Therefore, obtained findings by current study and the results of further studies based on additional markers will allow a more accurate assessment. Additionally, those kinds of intraspecific variations should be taken into account as the major indicators the documenting of Turkey's biodiversity. On the other hand, the steady karyotypes that are compatible with the previous findings could indicate a genetic homogeneity for other species examined in the study.

\section{Acknowledgement}

This study was supported by The Scientific and Technological Research Council of Turkey (TUBITAK) [grant number: 113Z822]. 


\section{References}

[1] Corbet, G.B., The mammals of the Palearctic region: a taxonomic review. British Museum (Natural History), Cornell University Press, London and Ithaca, 1978.

[2] Wilson, D.E., Reeder, D.M., Mammal Species of the World: A Taxonomic and Geographic Reference. 3rd ed. The Johns Hopkins University Press, Baltimore, 2005.

[3] Kryštufek, B., Vohralík, V., Mammals of Turkey and Cyprus. Rodentia I: Sciuridae, Dipodidae, Gliridae, Arvicolinae. Založba Annales, Koper, 2005.

[4] Arslan, A., Zima, J., Karyotypes of the mammals of Turkey and neighbouring regions: a review, Folia Zoologica, 63(1), 1-62, 2014.

[5] Zima, J, Macholán, M., Filippucci, M. G., Chromosomal variation and systematics of glirids, Hystrix, 6, 73-86, 1995.

[6] Doğramac1, S., Kefelioğlu H., The karyotype of Dryomys nitedula (Mammalia: Rodentia) from Turkey, Turkish Journal of Zoology, 14, 316-328, 1990.

[7] Arslan, A., Kankılıç, T., Yorulmaz, T., Kankılıç, T., Zima, J., Comparison of the chromosome banding patterns in Dryomys laniger and D. nitedula from Turkey, Turkish Journal of Zoology, 40(3), 363-368, 2016.

[8] Kıvanç, E., Die Haselmus, Muscardinus avellanarius L., in der Türkei, Bonner Zoologische Beiträge, 34(4), 419-428, 1983.

[9] Doğramac1, S., Türkiye Memeli Faunası, Ondokuz Mayıs Üniversitesi Fen Dergisi, 1(3), 107-136, 1989.

[10] Savic, I., Soldatovic, B., On the karyotype of Muscardinus avellanarius Linnaeus, 1758 (Rodentia, Gliridae), Arhiv Bioloških Nauka, 24, 7-8, 1972.

[11] Zima, J., Kral, B., Karyotypes of European mammals, II. Acta Scientiarum Naturilium, Academiae Scientarum Bohemoslovacae, 18, 1-62, 1984.

[12] Zima, J., Karyotypes of certain rodents from Czechoslovakia (Sciuridae, Gliridae, Cricetidae), Folia Zoologica, 36(4), 337-343, 1987.

[13] Belcheva, R.G., Topashka-Ancheva, M.N., Atanossov, N.I., Karyological studies of five species of mammals from Bulgaria's fauna, Comptes Rendus de I'Academie Bulgare des Sciences, 42, 125-138, 1988.

[14] Graphodatsky, A.S., Fokin, I.M., Comparative cytogenetics of Gliridae (Rodentia), Zoologicheskii Zhurnal, 72(11), 104-113, 1993.

[15] Peshev, D., Delov, V., Chromosome study of three species of dormice from Bulgaria, Hystrix, 6(1-2), 151-153, 1995.

[16] Zima, J., Macholan, M., Filippucci, M.G., Chromosomal variation and systematics of Myoxids, Hystrix, 6(1-2), 63-76, 1995.

[17] Şekeroğlu, V., Kefelioğlu, H, Şekeroğlu, Z.A., G- and C-banded karyotype of hazel dormouse, Muscardinus avellanarius trapezius (Mammalia: Rodentia) in Turkey, Turkish Journal of Zoology, 35, 375-379, 2011.

[18] Doğramac1, S., Kefelioğlu, H., Türkiye Muscardinus avellanarius (Mammalia: Rodentia) türünün karyotipi, Doğa-Turkish Journal of Zoology, 16, 43-49, 1992.

[19] Civitelli, M.V., Filippucci, M.G., Kurtonur, C., Özkan, B., Chromosome analysis of three species of Myoxidae, Hystrix, 6, 117-126, 1995. 
[20] Şekeroğlu, V., Şekeroğlu, Z.A., A chromosomal study of two dormouse species from Turkey, Hystrix 22, 301-309, 2011.

[21] Doğramac1, S., Tez, C., Geographic variations and karyological characteristics of the species Glis glis (Mammalia: Rodentia) in Turkey, Turkish Journal of Zoology, 18, 167-170, 1991.

[22] Arslan, A., Zima, J., Yorulmaz, T., Gözütok, S., Toyran, K., Chromosome banding pattern in fat dormouse and bank vole (Mammalia: Rodentia) from Turkey, Folia Biologica, 61, 47-51, 2013.

[23] Ford, C.E., Hamerton, J.L., 'A colchicine-hypotoniccitrate' squash sequence for mammalian chromosomes, Stain Technology, 31, 247-251, 1956.

[24] Seabright, M., A rapid technique for human chromosomes, Lancet, 2, 971-972, 1971.

[25] Sumner, A.T., A simple technique for demonstrating centromeric heterochromatin, Experimental Cell Research, 75, 304-306, 1972.

[26] Howell, W.M., Black, D.A., Controlled silver staining of nucleolus organizer regions with a protective colloidal developer: a 1-step method, Experientia, 36, 1014-1015, 1980.

[27] Levan, A., Fredga, K., Sandberg, A.A., Nomenclature for centromeric position on chromosomes, Hereditas, 52, 201-220, 1964.

[28] Şeker, P.S, Arslan A., Selvi, E., Kankılıç, T., Zima J., Variation in the Conventional and Banded Karyotypes among Populations of Arvicola amphibius (L., 1758) (Mammalia: Rodentia) from Turkey, Acta Zoologica Bulgarica, 70(1), 19-30, 2018.

[29] Kankılıç, T., Arslan, A., Şeker, P.S., Kankılıç, T., Toyran, K., Zima, J., A new chromosomal race $(2 n=44)$ of Nannospalax xanthodon from Turkey (Mammalia: Rodentia), Zoology in the Middle East, 63(3), 181-188, 2017.

[30] Mitsainas, G.P., Rovatsos, M.T., Karamariti, I., Giagia-Athanasopoulou, E.B., Chromosomal studies on Greek populations of four small rodent species, Folia Zoologica, 57(4), 337-346, 2008.

[31] Çağlar, M., Dryomys nitedula phrygius'un Anadolu'da yeni tespit edilen yaşama yerleri, İstanbul Üniversitesi Fen Fakültesi Mecmuas1, 27, 16-18, 1962.

[32] Helvac1, Z., Renaud, S., Ledevin, R., Adriaens, D., Michaux, J., Çolak, R., Kankılıç, T., Kandemir, I., Yiğit, N., Çolak, E., Morphometric and genetic structure of the edible dormouse (Glis glis): a consequence of forest fragmentation in Turkey, Biological Journal of the Linnean Society, 107, 611-623, 2012. 